Original Research Paper

\title{
Pengembangan Potensi Alam dan Lingkungan sebagai Daya Tarik Wisata (Studi Kasus Desa Wisata Sapit Lereng Rinjani)
}

\author{
Hailuddin $^{1 *}$, Mahyuddin Nasir ${ }^{1}$, Mukmin Suryatni ${ }^{1}$, Akung Daeng ${ }^{1}$, Satarudin $^{1}$, Sofiati Wardah $^{1}$ \\ ${ }^{1}$ Fakultas Ekonomi dan Bisnis, Universitas Mataram, Indonesia
}

https://doi.org/10.29303/jpmpi.v3i2.1391

Sitasi: Hailuddin., Nasir, M., Suryatni, M., Daeng, A., Satarudin \& Wardah, S. (2022). Pengembangan Potensi Alam dan Lingkungan sebagai Daya Tarik Wisata (Studi Kasus Desa Wisata Sapit Lereng Rinjani). Jurnal Pengabdian Magister Pendidikan IPA, 5(1)

\author{
Article history \\ Received: 10 Januari 2022 \\ Revised: 22 Februari 2022 \\ Accepted: 25 Februari 2022 \\ *Corresponding Author: \\ Hailuddin, Fakultas \\ Ekonomi Bisnis, Universitas \\ Mataram, Indonesia. Email: \\ didin@unram.ac.id
}

Abstract: Desa Sapit merupakan salah satu desa yang ada di Kecamatan Suwela Lombok Timur. Desa ini memiliki kesamaan dengan desa Sembalun karena sama-sama berada di lereng gunung rinjani. Sapit termasuk desa tua karena sudah ada sejak zaman penjajahan Belanda. Mengacu pada posisi geografisnya, desa Sapit memiliki posisi strategis karena dinaungi oleh gunung rinjani yang merupakan salah satu geopark dunia saat ini. Posisi inilah yang membuka peluang Sapit dapat memposisikan dirinya sebagai desa wisata yang bisa diandalkan. Potensi obyek wisata yang bisa dijual desa ini antaranya adalah alam dan lingkungan yang bernuansa pegunungan dan bukit. Hawa dingin dan sejuk selalu menyelimuti setiap orang yang berkunjung. Jika waktu pagi dan sore hari, orang bisa menikmati panorama puncak rinjani dengan begitu dekat. Lekuk puncak dan pepohonan yang diselimuti awan begitu jelas terlihat. Kalau mengarahkan pandangan kebawah (selatan), maka terlihat dengan jelas pantai Labuhan Lombok dan sekitarnya, hamparan Kecamatan Suwela, Pringgabaya bahkan kota Selong bisa dilihat dengan jelas terutama pada malam hari dengan kerlap kerlip lampunya. Selain alam, terdapat juga peninggalan sejarah berupa Pal Jepang diatas bukit, yaitu bangunan peninggalan Jepang sebagai simbul penguasaan Jepang saat perang dunia II. Pal ini bisa dijangkau dengan jalan kaki mendaki bukit kaki Rinjani selama 4 jam dari desa Sapit. Disekitaran Pal Jepang tersebut tersedia area untuk camping ground untuk para pencinta alam. Kelompok sadar wisata Desa Sapit selama ini kurang memahami potensi unggulan desa ini. Oleh karena itu tim pengabdian melakukan pendampingan, penyuluhan dan pencerahan mengenai pengembangan desa wisata, produk unggulan desa dan pemanfaatan rumah warga sebagai homestay. Pengabdian ini telah dilaksanakan dengan menggunakan model focus group discussion dan supervisi lapangan untuk identifikasi potensi-potensi tersebut.

Keywords: Penyuluhan pariwisata, Desa Wisata, focus group discussion, Homestay.

\section{Pendahuluan}

Pembangunan pariwisata belakangan ini cukup intensif dilakukan semua daerah terutama yang memiliki potensi dan daya tarik. Keadaan ini dimungkinkan karena sector pariwisata ini relative stabil pertumbuhannya meskipun dalam situasi perekonomian yang tidak menentu. Bahkan sangat bisa diandalkan untuk menjadi pendorong 
berkembangannya sektor-sektor lain secara simultan.

Salah satu trend yang menarik belakangan ini dan banyak tumbuh adalah pembangunan desa/kampung wisata. Hal ini dapat dimaklumi karena setiap desa/kampung memiliki kekhasan dan keunikan tersendiri. Kondisi-kondisi alamiah dan tradisional saat ini masih banyak ditemukan didaerah pedesaan, dimana masing-masing desa memiliki potensi dan karakteristik tersendiri.

Desa Sapit merupakan salah satu desa yang ada di Kecamatan Suwela Lombok Timur. Desa ini memiliki kesamaan dengan desa Sembalun karena sama-sama berada di lereng gunung rinjani. Desa Sapit termasuk katagori desa tua karena sudah ada sejak zaman penjajahan Belanda. Mengacu pada posisi geografisnya, desa Sapit memiliki posisi strategis karena dinaungi oleh gunung Rinjani yang merupakan salah satu geopark dunia saat ini. Posisi inilah yang membuka peluang Sapit dapat memposisikan dirinya sebagai desa wisata yang bisa diandalkan.

Potensi obyek wisata yang bisa dijual desa ini antaranya adalah alam dan lingkungan yang bernuansa pegunungan dan bukit. Hawa dingin dan sejuk selalu menyelimuti setiap orang yang berkunjung. Jika waktu pagi dan sore hari, orang bisa menikmati panorama puncak Rinjani dengan begitu dekat. Lekuk puncak dan pepohonan yang melingkupi serta dibalut awan tipis begitu jelas terlihat. Demikian juga jika kita arahkan pandangan kebawah (selatan), maka terlihat dengan jelas pantai Labuhan Lombok dan sekitarnya, hamparan Kecamatan Suwela, Pringgabaya bahkan kota Selong bisa dilihat dengan jelas terutama pada malam hari dengan kerlap kerlip lampunya.

Selain alam, terdapat juga peninggalan sejarah berupa Pal-Jepang diatas bukit, yaitu bangunan peninggalan Jepang sebagai simbul penguasaan Jepang atas Sapit saat perang dunia II. Pal ini bisa dijangkau dengan jalan kaki mendaki bukit kaki Rinjani selama 4 jam dari desa Sapit. Disekitaran Pal-Jepang tersebut tersedia area untuk camping ground yang cukup luas untuk memenuhi kebutuhan para pencinta alam.

Dengan konsisi tersebut, desa wisata Sapit menawarkan pengalaman baru, yaitu menyatu dengan alam pedesaan, menghurup udara segar, jauh dari polusi dan kebisingan. Selain itu para wisatawan tidak hanya dapat menikmati keindahan alam, tetapi juga bisa tinggal dan menginap agar dapat merasakan dan menikmati secara utuh alam dan social budaya di desa tersebut.

Karena itulah, menjadi kewajiban semua pihak terutama masyarakat Sapit sendiri untuk menggali, memanfaatkan, dan membangun sumber daya lokal yang selama ini kurang mendapat perhatian, berkreasi serta menjaga alam lingkungannya untuk keberlangsungan pembangunan desa Sapit kedepan. Upaya ini tentu akan memberi efek ganda bagi masyarakat berupa bangkitnya kesadaran warga dalam pelestarian budaya dan lingkungan, penataan dan penyiapan akomodasi berupa homestay yang hygiene dengan sanitasinya, munculnya kedai makan dengan menu lokal yang khas, bangkitnya kesenian rakyat desa dengan cindramatanya dan lainnya. Semua itu pada akhirnya akan mampu meningkatkan pendapatan yang mengarah pada perbaikan kesejahteraan masyarakat Sapit selanjutnya.

\section{Metode}

Untuk mencapai tujuan yang diharapkan dari kegiatan pengabdian masyarakat ini yaitu bangkitnya kesadaran masyarakat Sapit untuk pengembangan desanya sebagai desa wisata, maka metode yang digunakan untuk pemecahan masalah yang dihadapi masyarakat dan kelompok sadar wisata (Pokdarwis) desa Sapit adalah sebagi berikut:

a. Ceramah dan tanya jawab, dengan tokoh masyarakat dan kelompok sadar wisata (Pokdarwis) desa Sapit didampingi mahasiswa KKN dengan jumlah peserta sekitar 20 orang. Tim menjelaskan tentang strategi pengembangan desa wisata dengan mengoptimalkan potensi desa yang ada.

b. Melakukan supervisi lapangan sekaligus bimbingan ke lokasi tempat kegiatan produksi oleh-oleh (buah tangan) khas Sapit di dusun Rinayang. Jenis produknya adalah olahan produk pangan hasil pertanian/perkebunan berupa kopi bubuk arabika dan robusta, serbat jahe merah kemasan dan lainnya.

c. Memberi petunjuk dan menjelaskan konsep pengembangan desa wisata, yang dibantu mahasiswa KKN bekerjasama dengan dengan kelompok sadar wisata dengan membuat desain contoh wisata, kebersihan lingkungan dengan menyiapkan bak 
sampah keranjang kayu, membangun posko pusat informasi pariwisata desa, dan lainnya.

d. Pendampingan dan bimbingan secara online, khususnya kepada para remaja peduli wisata dan Pokdarwis setempat sesuai situasi dan waktu yang tersedia.

\section{Hasil dan Pembahasan}

Berdasarkan pelaksanaan kegiatan pengabdian yang telah dilakukan pada tanggal 22 Januari 2022, maka hasil yang diperoleh dari pelaksanaan kegiatan pengabdian ini adalah sebagai berikut :

1. Menguatnya pemahaman masyarakat tentang pentingnya pengembangan desa wisata untuk kemajuan desa.

Pemahaman pengembangan desa wisata ditunjukan kepada kelompok sadar wisata desa dan masyarakat Sapit umumnya. Mereka menjadi terbangun kesadarannya bahwa membangun usaha pariwisata tidak mesti dengan biaya mahal dan sulit. Namun yang utama adalah membangkitkan semangat dan harapan masyarakat secara bersama untuk menyuguhkan wisata yang alami dan dikelola dengan pendekatan konservasi dan penataan lingkungan yang mengedepankan keterlibatan masyarakat setempat. Masyarakat menjadi basis utama dalam pengembangan wisata ini, sehingga didapatkan poin penting yaitu tentang konservasi dan menjaga alam sekitar.

Berkaitan dengan hal tersebut, Ekowisata menjadi tujuan utama yang bila ditinjau dari perannya dalam hal konservasi, berarti lebih menjurus pada kelestarian lingkungan yang berkelanjuatan. Bila semua hal itu berjalan dengan baik, dengan pengelolaan dan pemanfaatan yang benar, tentu upaya ini akan berujung pada peningkatan pendapatan masyarakat setempat, dan ini dirasa sangat penting dan menjadi tujuan utama dalam menjalankan konsep pengembangan desa wisata berbasis eko-wisata. Oleh karena itu penyuluhan ini tidak hanya memberikan pemahaman mengenai pengembangan desa wisata tetapi juga menjelaskan bagaimana menjual/membuat paket wisata, bagaimana mengenalkan objek wisata, bagaimana deskripsi tentang objek tersebut, seperti apa akomodasi dan konsumsi, ketersdiaan sarana komunikasi dan transportasi, bagaiman link obyek wisata Sapit dengan obyek wisata lain diluar Sapit serta pendukung lainnya.

2. Pengembangan industry kreatif dan olahan pangan.

Ekonomi kreatif akan menjadi trend ekonomi dunia dalam beberapa tahun mendatang (Dharmawan, dkk. 2014). Oleh karena itu kreativitas dalam berkehidupan ekonomi yang memaksimalkan nilai tambah dari suatu produk barang dan jasa dalam rangka berkelanjutan kehidupan dan peradaban manusia mutlak diimplementasikan oleh semua masyarakat. Sehubungan dengan itu, kegiatan pengabdian ini dilaksanakan untuk memberikan pemahaman kepada masyarakat desa Sapit tentang bagaimana membangun kreativitas yang dapat menghasilkan nilai tambah atau pendapatan tambahan dari sector pariwisata. Kreativitasnya meliputi bagaimana masyarakat mampu untuk membuat kerajinan (craft) dengan bahan-bahan setempat dimana kegiatan yang berkaitan dengan kreasi, produksi yang berawal dari desain sederhana sampai proses penyelesaian produknya. Kain tenunan Sapit dengan corak khasnya, barangbarang kerajinan dari bambu, kayu, akarakaran, dan sejenisnya bisa dikreasikan.

Kreasi lainnya adalah hasil olahan pangan. Hasil pertanian/perkebunan cukup banyak ragamnya dari desa Sapit. Beberapa diantaranya yang sudah diolah adalah kopi bubuk arabika dan robusta, serbat jahe merah dan rempahnya, aneka kripik pisang dan singkong dan produk-produk olahan lainnya. Tentu produk ini akan sangat terbantu pertumbuhannya sejalan dengan kemajuan pariwisata.

3. Pengetahuan Pengelolaan Homestay

Homestay pada dasarnya merupakan tempat penginapan pola pedesaan sebagai usaha akomodasi di bidang pariwisata. Umumnya dibangun di daerah pedesaan (rural destination), yang pengadaannya diupayakan oleh masyarakat setempat. Jika makin banyak tamu yang berkunjung, tentu hal ini akan berdampak pada peningkatan permintaan homestay yang akhirnya akan mampu memberikan kesejahteraan bagi masyarakat 
desa. Ketersediaan tempat menginap di desa tentu akan sangat membantu para wisatawan untuk dapat merasakan dan mempelajari secara langsung lingkungan alam dan budaya setempat (hal-hal unik dan menarik), dimana antar satu desa dengan desa lainnya akan memiliki karakteristik yang berbeda.

Sehubungan dengan hal tersebut, tim pengabdian masuk dan memberikan edukasi kepada masyarakat desa Sapit agar tetap memelihara dan menjaga wilayah lingkungannya, khususnya lingkungan rumah yang akan dijadikan homestay, seperti menjaga kebersihan ruangan penginapan, peralatan makan minum, toilet, sanitasi dan lainnya. Disamping itu tim juga memberikan penyuluhan bagaimana berkomunikasi yang ramah dan sopan dengan para wisatawan, menciptakan dan menjaga kenyamanan dan keamanan lingkungan. Semua upaya tersebut tentu tidak lain maksudnya agar membuat para wisatawan menjadi betah untuk tinggal di penginapan/homestay yang disediakan.

4. Dengan metode dan pendekatan penyuluhan yang di laksanakan oleh tim pengabdian di desa Sapit diperoleh hasil bahwa pada dasarnya masyarakat mampu memahami dan menangkap peluang tentang bagaimana semestinya memanfaatkan potensi alam dan lingkungan pedesaan untuk dapat menjadi kawasan wisata (desa wisata). Kondisi ini terlihat dari keseriusan mereka dalam mengikuti diskusi dan supervisi lapangan, sekaligus menunjukkan aktivitas yang sudah mulai dilakukan seperti penataan kebersihan lingkungan, penanganan sampah, penanaman pohon pelindung dijalan raya, penyiapan pos informasi pariwisata, pengaktifan kegiatan Pokdarwis desa Sapit, adanya rencana untuk membangun lapak/kios-kios souvenir dan lainnya. Semua kegiatan tersebut sebagian sudah mulai berjalan dan dalam proses pelaksanaan yang dibantu oleh adik-adik mahasiswa KKN Unram.

\section{Kesimpulan}

Berdasarkan hasil dan pembahasan diatas, dapat disimpulkan beberapa hal antaranya :

1. Potensi alam dan lingkungan Desa Sapit sangat mendukung untuk dapat dijual sebagai daya tarik wisata pedesaan yang potensial.

2. Masyarakat Desa Sapit belum sepenuhnya menyadari potensi alam dan lingkungan yang mereka miliki, yang dapat dikembangkan sebagai daya tarik (obyek) wisata alam.

3. Kelompok sadar wisata (pokdarwis) yang ada didesa Sapit belum maksimal melakukan kegiatan pengembangan wisata desa. Hal ini terlihat dari belum adanya upaya promosi wisata, paket wisata dan penataan obyek wisata yang ada secara optimal.

4. Masyarakat secara umum sudah mulai mempersiapakan produk-produk lokal industry creative sebagai oleh-oleh (cendramata) baik olahan makanan maupun kerajinan tenunan.

5. Dan yang terakhir, masyarakat sudah mulai memahami konsep homestay, dengan kegiatan mulai membersihkan lingkungan, penanganan sampah rumah tangga, penataan nama-nama gang dan persiapan lainnya terutama yang berkaitan dengan penyediaan homestay.

\section{Daftar Pustaka}

Dharmawan, dkk. 2014. Strategi Pengembangan Desa Wisata di Desa Belimbing Kecamatan Pupuan Kabupaten Tabanan. Universitas Udayana, Tesis, Prodi Agribisnis.

Gamal Suwantoro, 1997. Dasar-dasar Pariwisata. Andi Publisher, Yogyakarta.

Hadiwijoyo, Surya Sakti, 2012. Perencanaan Pariwisata Perdesaan Berbasis Masyarakat (Sebuah Pendekatan Konsep). Yogyakarta: Graha Ilmu.

Pitana, I. Gede dan Diarta, I Ketut Surya. 2009. Pengantar Ilmu Pariwisata. Yogyakarta: CV Andi Offset.

Thandi A. Nzama, 2010. Challenges of Suistainable Rural Tourism Development in Kwazulu-Natal. Journal Hum \& Soc. Sci 2(1): 44-53

Utomo dan Satriawan, 2017. Strategi Pengembangan Desa Wisata di Kecamatan Karangploso Kabupaten Malang. Universitas Trunojoyo Madura, Tesis, Prodi Ekonomi Pembangunan.

Urbanus Ambardi dan Socia Prihawantoro, (Editor), 2002. Pengembangan Wilayah dan Otonomi Daerah - Kajian Konsep dan Pengembangan, BPPT Press., Jakarta. 